\title{
BIG-registratie als brevet
}

Begin 1998 maakte ik mijn debuut als journalist bij De Psycholoog. Voor mij was het evident waar het eerste artikel over zou moeten gaan: de gezondheidszorgpsycholoog, die op het punt stond erkend te worden als BIG-beroep. Groot was dan ook mijn verbazing toen de (wetenschappelijke) redactie van niets bleek te weten. 'Gezondheidszorgpsycholoog'? Wist ik zeker dat het niet 'gezondheidspsycholoog' was? En dat was toch een wetenschappelijke deeldiscipline, geen beroep? Trouwens, waarom zou die titel beschermd moeten worden? Alsof iemand het in zijn hoofd zou halen om zo'n idiote beroepstitel te gebruiken als hij er geen recht op had.

Inmiddels weten we beter. 'Gz-psycholoog' is een titel met status geworden. Studenten verdringen zich om optimaal voor te sorteren op de GZ-opleiding.

Afgestudeerden zijn bereid gemiddeld vijf jaar te wachten op een opleidingsplaats, instellingen vechten om opleidingssubsidies en vacatures blijken moeilijk op te vullen.

Tegelijkertijd laait, als een veenbrand, telkens weer de discussie op over de meerwaarde van de gz-psycholoog. Recent bijvoorbeeld weer, in een LinkedIn-discussie over het tekort aan gz-psychologen:

'hoe het bestaat dat zo veel, zeer bekwame psychologen NIP met veel kennis, ervaring en uitstekende contactuele eigenschappen links worden gelaten, worden genegeerd', zo vraagt ene Pjotr K zich retorisch af.

Heeft Pjotr gelijk? Helemaal wel, en tegelijk helemaal niet. Helemaal wel: enerzijds is niet elke gz-psycholoog bekwaam, en natuurlijk zijn er niet-BIG-geregistreerde psychologen en pedagogen die hun werk even goed of zelfs beter doen. Maar anderzijds: datzelfde kan gezegd worden van chauffeurs zonder rijbewijs, piloten zonder vliegbrevet, of mensen die artsenij, fysiotherapie of verpleegkunde bedrijven zonder... juist, BIG-registratie.

Toch vragen we ons nooit af wat de meerwaarde is van een rijbewijs, een vliegbrevet of een BIG-registratie voor dokters. Waarom dan telkens wel weer de discussie over de betekenis van de BIG-registratie voor psychologen? Allerlei verklaringen schieten door het hoofd: universiteiten die ongebreideld studenten opleiden en voorspiegelen dat ze zonder BIG-registratie aan de slag kunnen, beroepsverenigingen die net doen of verenigingsregistraties eenzelfde status hebben (ooit gehoord van de arts-KNMG of de fysiotherapeut-KNGF?). Maar de belangrijkste verklaring is toch misschien wel dat in de praktijk soms bijna geen verschil is tussen

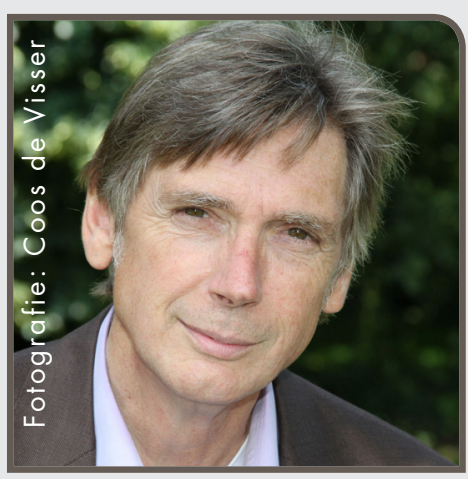

wel- en niet-BIG-geregistreerde psychologen. Vaak werken ze zij aan zij, zonder dat duidelijk is wat de grenzen zijn van de bevoegdheid van een niet-geregistreerde. Vergelijk dat met de huisarts of de tandarts, waar een niet-BIG-geregistreerde op eigen gezag nog geen wratje mag verwijderen of gaatje mag vullen (geruststellend gevoel, vind ik altijd als patiënt.)

In de ggz was er een declaratieschandaal (EuroPsyche) nodig om tot uniforme afspraken te komen over BIG-registratie als voorwaarde voor een rol als zelfstandig (regie)behandelaar. Laten we hopen dat dit voorbeeld de komende jaren navolging krijgt in andere sectoren, liefst zonder dat daar een schandaal of misstand aan te pas hoeft te komen; zodat we over vijf jaar kunnen zeggen dat BIG-registratie echt de standaard is voor psychologen in de zorg, net als voor die andere BIG-beroepen. 